\title{
Amino Acid in Gastric Juice of Peptic Ulcer Patients
}

\author{
Kose Sfgawa, MD, Saburo Nakazawa, MD, Yoshihisa Tsukamoto, MD, \\ Eiji Kobayashi, MD, Hatsuhiro Yamaguchi, MD \\ and Hidemi Goto, MD
}

\begin{abstract}
To clarify the protein metabolism in peptic ulcer disease, the amino acid content was determined in gastric juice of gastric ulcer patients $(n=30)$, duodenal ulcer patients $(n=16)$, gastroduodenal ulcer patients $(n=8)$, and hospital controls $(n=8)$. The amino acid output in the gastric ulcer group was greater than that of the hospital control both in basal and maximal secretion. In the duodenal ulcer group of patients who were high secretors of gastric juice, the amino acid concentration was low, so the amino acid output was also lower than that of the hospital control group. Tetragastrin did not increase the amino acid output in the gastric juice. The amino acid amount may be decided also by the architecture of the gastric mucosa and not only by the ulcer lesion itself. The protein loss from gastric mucosa may well result in hypoproteinemia in peptic ulcer disease of the stomach.
\end{abstract}

Key Words: Amino acid, Protein loss, Peptic ulcer, Hypoproteinemia.

The protein loss from the stomach sometimes induces hypoproteinemia in various stomach diseases $^{1-4)}$. The serum protein of peptic ulcer in the active stage was lower than that of normal control $^{5-7)}$. The reduction of serum protein was more conspicuous in gastric ulcer than duodenal ulcer cases ${ }^{5,6)}$. This may result from various etiologies such as bleeding from the ulcer lesion, and decrease of food intake induced by abdominal pain.

There are many reported studies on amino acid content in gastric juice using the thin-layer chromatography ${ }^{8)}$ or paper-chromatography ${ }^{9,10)}$. In the present investigation, the determination of the amino acid content of gastric juice was undertaken using the method of Ninhydrin reaction ${ }^{11)}$ in patients with gastric ulcer, duodenal ulcer, gastroduodenal ulcer and hospital control before and after stimulation by tetragastrin, in order to elucidate the protein metabolism in peptic ulcer.

\section{MATERIALS AND METHODS}

Patients The subjects were out and hospitalized patients of our hospital (Table 1). They consisted of 14 hospital controls, 30 patients with gastric ulcer, 16 with duodenal ulcer and 8 with gastroduodenal ulcer. The hospital controls were patients with some gastrointestinal complaints who were diagnosed to have no organic disease in the digestive tract other than minimal chronic gastritis. The diagnosis was confirmed by X-ray and endoscopic examination including the pathologic study. The mean age in each group of patients was as shown in Table 1. The difference in the mean age between the hospital control group and the duodenal ulcer group was statistically significant ( $p<0.05$ ), but there was no statistically significant difference between hospital control group and each of the other groups.

Method of collecting gastric juice The gastric secretory study was performed following the

From The Second Department of Internal Medicine, Nagoya University School of Medicine

(Director: Prof. Tatuo Satake, MD).

Received for publication July 21, 1984.

Reprint request to: Kose Segawa, MD, The Second Department of Internal Medicine,

Nagoya University School of Medicine, 65 Tsuruma-cho, Showa-ku, Nagoya 466, Japan. 
Table 1. The subjects for study.

\begin{tabular}{lrrr} 
& Number & m:f & Age $(y)$ \\
\hline Hospital Control & 14 & $7: 7$ & $48.1 \pm 3.7$ \\
Gastric Ulcer & 30 & $27: 3$ & $49.4 \pm 2.3$ \\
Duodenal Ulcer & 16 & $14: 2$ & $34.3 \pm 3.3$ \\
Gastroduod Ulcer & 8 & $8: 0$ & $51.5 \pm 5.1$ \\
Total & 68 & $56: 12$ & \\
\hline
\end{tabular}

$($ Mean $\pm S E)$

method of the Japanese Society of Gastroenterology ${ }^{12)}$. After an overnight fast, a gastric tube with balloon was inserted into the stomach and in the left decumbent position gastric secretion was collected every 10 minutes. After six basal collections (basal secretion), the patients were given an intramuscular injection of $4 \mu \mathrm{g} / \mathrm{kg}$ of tetragastrin and a further six collections (maximal secretion) were made.

Amino acid assay After estimation of gastric acidity by titration of $0.1 \mathrm{~N} \mathrm{NaOH}^{13)}$, samples were pooled as basal and maximal secretion, and were subjected to the assay of total amino acids in the following procedure. Gastric juice was centrifuged for 5 minutes at 2,500 rpm and $0.1 \mathrm{ml}$ of the supernatant was mixed with 1.5 $\mathrm{ml}$ of ethanol-acetone (1:1) solution. The mixture was stirred for 20 minutes at room temperature, and was centrifuged again to remove protein. The supernatant was mixed with $2 \mathrm{ml}$ of Ninhydrin solution and $0.1 \mathrm{ml}$ of phosphate buffer as the method described ${ }^{11)}$. This mixture was heated in boiling water for 20 minutes and consequently cooled in ice water. Then, the total volume was adjusted to $10 \mathrm{ml}$ by adding methanol. The absorbance was measured by spectrophotometer (Hitachi Model 100-40, Japan) set at the wavelength of $580 \mathrm{~nm}$. Glycine solution (10 or
$20 \mathrm{mg} / \mathrm{dl}$ ) was used as a standard for amino acid determination. The concentration of amino acids in gastric juice $(\mathrm{mg} / \mathrm{dl})$ was multiplied by the secretory volume (ml/hour) and the output of amino acid in gastric juice was expressed as $\mathrm{mg} /$ hour.

Protein assay in gastric juice Each of the gastric juice was subjected to the assay of protein as well as amino acid by the method of Lowry ${ }^{14}$ ) to correlate with amino acid determined by Ninhydrin method.

Statistics Statistical analyses were carried out using Student's t-test ${ }^{15}$. The difference among means of data was considered significant when $\mathrm{p}<0.05$.

\section{RESULTS}

Gastric secretory volume Basal volume rate (BVR) and maximal volume rate (MVR) in each group of patients were as shown in Table 2. In basal volume rate, there was a statisfically significant difference between hospital controls and duodenal ulcer groups $(p<0.05)$, as well as between the same controls and gastroduodenal ulcer patients $(p<0.01)$. In maximal volume rate, there was a statistically significant difference between hospital controls and gastric ulcer cases $(p<0.01)$, hospital controls and duodenal ulcer patients $(p<0.01)$, and between hospital controls and gastroduodenal ulcer cases $(\mathrm{p}<0.01)$.

Gastric acid output Basal acid output (BAO) and maximal acid output (MAO) in each group of patients were as shown in Table 2. In BAO, there was a statistically significant difference between hospital control and duodenal ulcer $(\mathrm{p}<0.05)$, hospital control and gastroduodenal ulcer $(\mathrm{p}<0.01)$, and gastric ulcer and gastro-

Table 2. Secretory volume and acid output.

\begin{tabular}{|c|c|c|c|c|}
\hline & \multicolumn{2}{|c|}{ Volume $\operatorname{Rate}(\mathrm{ml} / \mathrm{h})$} & \multicolumn{2}{|c|}{ Acid Output (mEq/h) } \\
\hline & BVR & MVR & BAO & MAO \\
\hline $\begin{array}{l}\text { Hospital Control } \\
\text { Gatric Ulcer } \\
\text { Duodenal Ulcer } \\
\text { Gastroduod Ulcer }\end{array}$ & $\begin{array}{r}52.33 \pm 8.07 \\
73.77 \pm 8.45 \\
79.96 \pm 10.52 \\
113.98 \pm 15.83\end{array}$ & $\begin{array}{r}85.69 \pm 16.87 \\
152.27 \pm 17.26 \\
159.66 \pm 13.86 \\
135.14 \pm 13.36\end{array}$ & $\begin{array}{l}0.86 \pm 0.44 \\
1.58 \pm 0.38 \\
4.09 \pm 1.24 \\
4.69 \pm 1.42\end{array}$ & $\begin{array}{r}5.50 \pm 1.32 \\
10.81 \pm 1.95 \\
14.34 \pm 1.70 \\
9.80 \pm 2.02\end{array}$ \\
\hline
\end{tabular}

(Mean \pm SE) 


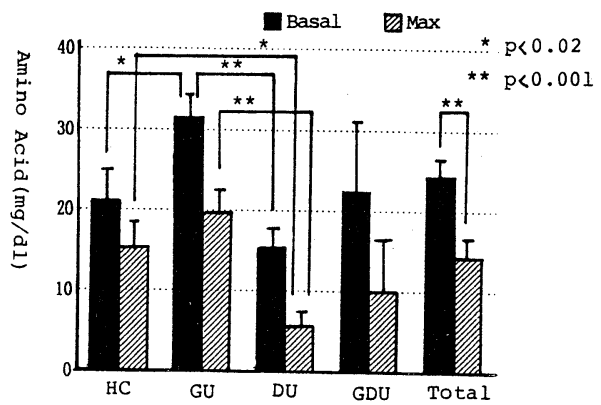

Fig. 1. The amino acid concentration of gastric juice before and after stimulation by tetragastrin $(4 \mu \mathrm{g} / \mathrm{kg})$ in hospital control group $(n=14)$, gastric ulcer group $(n=30)$, duodenal ulcer group $(\mathrm{n}=16)$, and gastroduodenal ulcer group $(n=8)$. The total $(n=$ 68 ) comprises each of the above.

duodenal ulcer $(\mathrm{p}<0.05)$. In MAO, the statistically significant difference existed between hospital controls and gastric ulcer $(p<0.05)$, and between hospital controls and duodenal ulcer $(\mathrm{p}<0.001)$.

Amino acid The amino acid concentration in gastric juice before and after stimulation by tetragastrin was as shown in Figure 1. In the amino acid concentration of basal secretion, there was a statistically significant difference between the mean value of hospital control group and that of gastric ulcer group $(p<0.02)$, and between those of gastric ulcer and duodenal

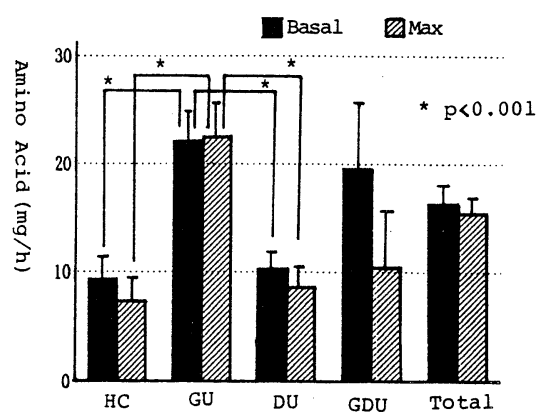

Fig. 2. The amino acid output of gastric juice before and after stimulation by tetragastrin $(4 \mu \mathrm{g} / \mathrm{kg})$ in hospital control group $(n=14)$, gastric ulcer group $(n=30)$, duodenal ulcer group $(n=16)$, and gastroduodenal ulcer group $(n=8)$. The total $(n=68)$ comprises each of the above. ulcer $(\mathrm{p}<0.001)$. In the amino acid concentration of maximal secretion, a statistically significant difference existed between the mean value of hospital control and duodenal ulcer $(\mathrm{p}<0.02)$ and between those of gastric ulcer and duodenal ulcer $(\mathrm{p}<0.001)$. Among all 68 patients including hospital control, gastric ulcer, duodenal ulcer, and gastroduodenal ulcer, the amino acid concentration was $24.5 \pm 1.93 \mathrm{mg} / \mathrm{dl}$ in basal secretion, and $14.45 \pm 1.70 \mathrm{mg} / \mathrm{dl}$ in maximal secretion. There was a statistically significant difference between the amino acid concentration of basal secretion and maximal secretion $(p<0.001)$.

The amino acid output in gastric juice before and after stimulation by tetragastrin was as shown in Figure 2. In basal output, there was a statistically significant difference between hospital control and gastric ulcer $(p<0.001)$, and gastric ulcer and duodenal ulcer $(\mathrm{p}<0.001)$. In maximal output, there was a statistically significant difference between the mean value of hospital control and gastric ulcer $(p<0.001)$, and between gastric ulcer and duodenal ulcer $(\mathrm{p}<0.001)$. Among all 68 patients including hospital controls, and those with gastric ulcer, duodenal ulcer and gastroduodenal ulcer, total amino acid output was $16.31 \pm 1.71 \mathrm{mg} / \mathrm{h}$ in basal secretion, and $15.39 \pm 1.87 \mathrm{mg} / \mathrm{h}$ in the maximal secretion. There was no statistically significant difference between amino acid output in basal and maximal

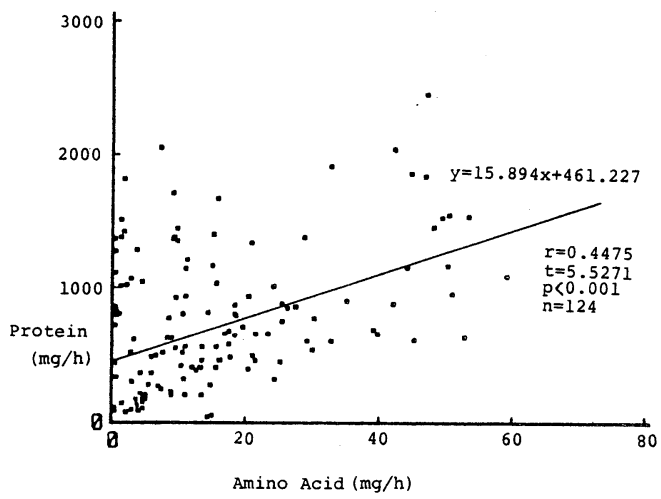

Fig. 3. The correlationship between the protein content in gastric juice determined by Lowry's method and that of amino acid determined by Ninhydrin method. A statistically significant correlationship was found $(p<0.001)$. 
secretion.

There was a statistically significant correlationship between the amino acid content determined by the Ninhydrin method and that of protein determined by Lowry's method $(\mathrm{p}<0.001)$ (Figure 3).

\section{DISCUSSION}

In a series of peptic ulcer patients hospitalized in our institution from 1970 to 1983 , the serum protein of gastric ulcer patients, who did not suffer from hematemesis or melena, was $6.52 \pm$ 0.64 (mean $\pm \mathrm{SD}$ ) $\mathrm{g} / \mathrm{dl}$ in the active stage and that of the same patients was $6.85 \pm 0.41 \mathrm{~g} / \mathrm{dl}$ in the stage of scar. There was a statistically significant difference between both values. Kageyama ${ }^{5)}$ reported that the serum level of total protein was $6.70 \pm 0.13$ (mean $\pm \mathrm{SD}$ ) $\mathrm{g} / \mathrm{dl}$ in normal subjects, $6.56 \pm 0.79 \mathrm{~g} / \mathrm{dl}$ in gastric ulcer and $6.81 \pm 0.92 \mathrm{~g} / \mathrm{dl}$ in duodenal ulcer. There are many reasons for the reduction of serum protein in peptic ulcer disease. The protein loss from the gastric wall is one of the etiologies. The amino acid content of gastric juice was determined in the present study as an approach to this problem.

Peptides in gastric juice come from various origins such as mucosal debris, the serum protein shed from any lesions, secretory $\operatorname{IgA}$, gastric mucus, and digested food. In this study, the assay of amino acid in gastric juice was performed by the Ninhydrin method ${ }^{11)}$, which was simple and sensitive ${ }^{12)}$. The value assayed by Ninhydrin reaction method correlated with the value assayed by Lowry's method ${ }^{14)}$.

The gastric secretory volume and acid output increased by the stimulation of tetragasttin, whereas, the amino acid concentration decreased after stimulating gastric secretion by tetragastrin. Thus, the total amino acid output did not change before and after stimulation by tetragastrin, which indicated that tetragastrin did not increase the amino acid output in the gastric juice. The secretory volumes of gastric juice in gastric ulcer, duodenal ulcer and gastroduodenal ulcer patients were greater than that of hospital control. The amino acid output in the gastric ulcer group was greater than that of hospital control both in basal and maximal secretion. There was much variation in the amino acid values within the gastroduodenal ulcer group, while the mean value existed between gastric ulcer an duodenal ulcer. This suggests that a gastroduodenal ulcer has both duodenal and gastric ulcer characteristics. Among the four groups investigated, the content of amino acid in gastric juice showed the lowest value in the duodenal ulcer group, although the secretory volume and gastric acid output were the greatest. This indicates that the acid and protease in gastric juice does not exert an effect on the amino acid content in the gastric juice, which is measured by the Ninhydrin method.

The protein, peptide, and amino acid in gastric juice move down to the lower intestine, and can be reabsorbed there and may enter the blood stream again. Too much escape of them into the gastric juice, however, may induce hypoproteinemia of the host. The reason why the quantity of amino acid in gastric juice differs for the gastric ulcer, duodenal ulcer, and gastroduodenal ulcer has not been confirmed in this study. One of the probable reasons is that the protein lost from the duodenal ulcer lesion does not move into the gastric juice. The major key reason may, however, be the difference in the mucosal architecture of the stomach. The architecture of the gastric mucosa is different in a gastric or a duodenal ulcer. This may play a role in the etiology, as in Menetrier's disease, in which much peptide lost from the gastric mucosa), and in Dunzendorfer's report ${ }^{8}$ ) of high amino acid content in gastric juice of a patient with chronic atrophic gastritis. The authors consider that, in addition to the ulcer lesion itself, protein may be lost from the gastric mucosa around the ulcer and increase the amount of peptide in gastric juice. In other words, the patient with a gastric ulcer in the active stage loses much peptide from the mucosa of accompanying gastritis around the ulcer. Some mechanism which mobilizes protein from the gastric mucosa into gastric juice exists in the active stage of gastric ulcer. The assay of glycoprotein and analysis of amino acid ${ }^{16)}$ in gastric juice referring to the morphology of gastric 
mucosa, may well provide clues to solve the problem.

\section{REFERENCES}

1) Kondo $M$, Nishibori $H$, Ikezaki $M$, et al: A case of Menetrier's disease associated with protein-losing gastropathy and abnormal serum profile. Gastroenterol Jpn 13: 297, 1978.

2) Clarke AC and Nicholson GI: Gastritis variformis. Chronic erosive gastritis with protein-losing gastropathy. Am J Gastroenterol 68: 599, 1977.

3) Waldum HL, Burhol PG, Nordoe A, et al: Proteinlosing gastropathy with gastric hypersecretion of acid $\left(\mathrm{H}^{+}\right)$, pepsin and hypergastrinemia. A case report. Acta Hepato-Gastroenterol 24: 296, 1977.

4) Jarnum S and Jensen KB: Plasma protein turnover (albumin, transferrin, IgG, IgM) in Menetrier's disease (giant hypertrophic gastritis): Evidence of non-selective protein-loss. Gut 13: 128, 1972.

5) Kageyama T: Paper electrophoretic studies on serum proteins in the diseases of the digestive system, with particular reference to the change in serum proteins in the patient with cancer. Bull Osaka Med Sch 9: 62, 1963.

6) Berndt H: Das Bluteiweissbild bei Ulcus Pepticum. D tsch Z Verdau Stoffwechselkr 24: 21, 1964.

7) Fodor $O$ and Grigoras D: Untersuchungen über die Bedeutung der Dysproteinaemie bei Ulkuskrankheit. Ärtzliche Forschung 17: 32, 1963.
8) Dunzendorfer U: Klinische Bedeutung der Amino Säure in Magensaft. Münch Med Wschr 118: 1495, 1976.

9) Oh-Uchi $\mathrm{K}$ and Awataguchi J: Free amino acids in gastric juice of patients with gastric or duodenal ulcer and gastric carcinoma, with special reference to the change after operation. Tohoku J Exp Med 67: $123,1958$.

10) Heathrote JG and Washington RJ: Peptide of normal human gastric juice. Int $\mathrm{J}$ Protein Research 11: $117,1970$.

11) Rodwell VW: Amino acids and peptides, chap 3. Review of physiological chemistry (Harper HA, Rodwell VW and Mayes RA, etd), Lange Medical Publications, Los Altos, p 18, 1979.

12) Yamagata $S$, Ishimori $A$, Sato $H$, et al: Secretory function of the stomach of Japanese with endoscopically normal gastric mucosa. Gastroenterol Jpn 10: 162, 1977.

13) Segawa K, Nakazawa S, Naito $Y$, et al: The further investigation on the gastric acid secretion in primary hyperparathyroidism. Gastroenterol Jpn 12: 347, 1977.

14) Lowry OH, Rosebrough NJ, Farr AL, et al: Protein measurement with Folin reagent. J Biol Chemist 193: 265, 1951.

15) Siegal S: Nonparametric statistics for the behavioral sciences, Mc-Grawhill, New York, p 248, 1956.

16) Streyer L: Biochemistry, 2nd ed, WH Freeman \& Co, San Francisco, 1975, p 22. 